\title{
Bőrcserző és bőrlábbeliket készítő kézművesek a csurgói „Magyar Céhben” (1810-1872)
}

\author{
KNÉZY JUDIT \\ H-1149 Budapest, Pillangó park 16/b. fsz.2., e-mail: jknezy@freemail.hu
}

\begin{abstract}
KNÉZY, J.: Leather tanning and leather footwear maker masters in the Hungarian Guild of Csurgó markettown from 1810 until 1872.

Abstract: In the studies and works concerning the clothing of the common people living in Somogy county their footwear are rarely mentioned. The examination of the local Guilds' paperwork can fill these gaps in our knowledge. One can find there detailed description of cuts and masterpieces, treaties and bills of the guilds' workers, and cash books. This study examines the written data of the so called 'Hungarian' Guild in the markettown of Csurgó in the time between 1810 and 1872 , as this was the exact time when the usage of footwear began to follow quicklier the pattern of larger towns' clothing habits.
\end{abstract}

Keywords: leather processing, the products of footwearshoe-maker craftsmen, the 'Hungarian', 'western' and 'Turk' methods of leather processing, independent skin-dresser, cobbler and boot-maker guilds, the leather shoe-making masters of the 'Mixed' guild in Csurgó between 1810 and 1872, masterpieces, contracts of apprentices

\section{A téma előzményei és indokolása}

Korábbi tanulmányomban elemeztem a csurgói kézművesek történetére, tevékenységére vonatkozó iratokból a viszonylag későn szerveződött ún. vegyes céh (1810) ${ }^{1}$ alakulásának körülményeit. Ez rövidesen kettévált „Külső” vagy „Német” és „Belső” vagy „Magyar" Céhhé 1814-ben. ${ }^{2}$ Más munkámban ismertettem a Német céhbe tartozó pék és mézesbábos iparosok adatait. ${ }^{3}$ Ezt követte az itteni Belső illetve Magyar céh takácsaira, szür-, magyar-, német-, vásári-, asszonyilletve lajbi-szabóira vonatkozó szórványadatok elemzése. ${ }^{4}$ A 19. század első két harmada a csurgói és környéki paraszti viselet kiszínesedésének, szerkezeti átalakulásának korszaka, amely egybeesik a céhek müködésének utolsó fél évszázadával. $E$ folyamatban fontos szerepet játszottak nemcsak a kézművesek, de a kereskedőhálózat is. Jelen munkám a magyar vagy belső céhbe tartozó, a bőrcserző mesterekkel és bőrből való lábbelik készítésével foglalkozó iparosokkal foglalkozik, akik a 19. századi lábbeli divatok változásaiban szintén feladatot vállaltak.

1 Somogy Megyei Levéltár (a továbbiakban SML) IX. Testületek, céhek. 3. Csurgói céhek

2 Knézy J. 2012. 193-203. A 2010. májusi Veszprémben tartott kézmüvesipari konferencia előadása.

3 VEAB Kézműves Mühely kenyér konferenciájára írt előadás. Megjelent Knézy J. 2013. 251- 260.

4 A VEAB kézmüves Mühely 2012. évi textilkonferencián elhangzott előadása, jelenleg nyomdában

ISSN 2064-1966 (Print); ISSN 2631-0376 (Online)

\section{A bőrt és bőrlábbelit készítő iparosok csoportjai, profilja a középkortól a 18. század végéig}

A török hódoltság alatt céhek működéséről nem tudunk e területen. De a népesebb helységekben tevékenykedtek a helyi és a törökökkel érkező török illetve balkáni iparosok is. Különösen a katonaságot ellátó szabók és lábbeli készítők élveztek előnyöket. Közülük a harcok elültével sokan a megyében maradtak a népesebb helyeken. Ezek a szabók, vargák és csizmadiák kérték először a céh kiváltságokat. Szádeczky Kardos feltételezése szerint Kaposvárott a fontosabb iparosok a 18. század elején még a hajdúk által alapított csizmadia (1696. ápr. 6.), és szabó (1698.szept.7) céhek tagjai voltak.(1700.dec.5.). ${ }^{5}$ Szigetváron is a szabók (1700. dec. 5.) és csizmadiák (1701.) szerveződése sikerült ekkoriban. ${ }^{6}$

Török hódoltság idején a börcserzés technikájának szélesebb skálája alakult ki. A már meglévő zsírcserzés, árványi sókkal való cserzés, a külföldiek által magyar módra ${ }^{7}$ valónak tartott bőrkikészítési technika mellé - mely a tímároknevéhez füződik, - és a vargák által végzett részben nyugati eredetü hosszadalmas növényi cserzés mellett - török, illetve más a Balkánról jött iparosok által közvetített újabb eljárások váltak ismertté. Utóbbi másfajta, de szintén növényi cserzéssel történt és másfajta pácolással. A tímárok a bőrről a szőrt kaszaszerü késsel kaparták le, majd timsós illetve konyhasós lében áztatták. Száradás után izzó parázs felett faggyúval, zsírral kenve teltek meg a pórusok, ettől vízhatlanná vált. Hajlékony, nagy szakítószilárdságú bőr készült ily módon. Puha lábbelinek volt alkalmas bocskornak, pántos vagy más sarunak. A 15-16. században többrétegü, vastag talpú, száras saru is készült már. A.vargák már a középkorban alkalmazták a növényi cserzést kádakban, gödrökben áztatva a bőrt, melyet felaprított fenyő-, cser-, tölgykéreg és gubacs vízzel telített ázalékában tartottak hónapokig. ${ }^{8}$ Így cserződtek a viszonylag vastag ún. fontos vagy funtos talpak. A cserszömörce Dél-Euró-

5 Szádeczky Kardos L. 1913. Kanyar J. 1967. 96. Közben a város elpusztult, de hamar újra betelepült.

6 Kiss I. 1962. 88. E céhek sorsa mostoha volt, többször visszavonták, majd újra megadták kiváltáságaikat.

7 Puha lábbelit tudtak belőle készíteni bocskort, pántos sarut. A 15 16. században többrétegü vastag talpú száras sarut. Gáborján $A$. 1962. 97-140. Flórián M. 1999. 6.

8 A funtos talpak nagyon keresettek voltak az árszabások szerint a 17-19. században. Varga, cseres tímár, cserzővarga nevekkel illették ezeket az iparosokat. 
pából történő meghonosításával az arab, mór eredetű föképp töröknek nevezett kezeléssel sokkal gyorsabban értek el eredményt. A Kárpát-medencében e metódust használókra vonatkozott a tobak név. Művelői a tobakosok, kordovánosok lábbeli készítéssel nem foglalkoztak. ${ }^{9}$ Szömörcével dolgoztak és meszezéssel szőrtelenítették a bőrt. A meszet páccal távolították el, madár, baromfi. kutya ganajának levével. A 18. század eleji vármegyei árszabások egyaránt árazták a tímárok: által előállított (ökör-, tehén-, tinó-, üsző- és borjúbőrt, funtos talp párokat) és a tobakosok kikészítette bőrféleségeket (csizmabélésnek való bárány vagy kecske bör, lábbeli külsejének is alkalmas pécsi, kaposi, koppányi stb. kordován, karmazsin, szattyán). 1737-ben emlegették a lengyel csizmát, ennek a belső szárrésze kissé rövidebb volt, mint a külső. ${ }^{10}$

Újfajta török készítmények is megjelentek, mint a szárát, talpát fordított varrással egymáshoz rögzített egytalpú csizma, papucs, de török saruk is (sarkatlan, béleletlen) köztük cikkelyesek is. Ezek alapanyaga a fekete kordován, a sárga vagy veres karmazsin, nőknek inkább a gyengébb szattyán. A 17 . századi török csizma „egy varrással készült, toldás nélkül”, sima volt a sarka, egyenes a talpa. A közrend még nem vásárolhatta piacon, legfeljebb görög kereskedőktől. A papucs lehetett igen magas sarkú is, ez vasból való is.. ${ }^{11} \mathrm{~A}$ zsoldosokat nagyszámú iparos követte a Balkán felöl, hatásuk hamarosan megmutatkozott. Föképp Pécs városában, Somogyban pedig Koppány, Lak, Szilvásszentmárton, Kaposvár, Görösgál, Turbék, Segesd és Berzence községekben működtek. A harcok elültével Pécsre, Szigetvárra, Kaposvárra, Igalba, Karádra, Kéthelyre húzódtak be, vagy ha ott laktak, ott is maradtak. ${ }^{12} \mathrm{~A}$ vargák, csizmadiák árui komoly összegbe kerültek esetenként és a földesurak, előjárók felé közvetítették az új divatot is. A kamarai összeírásokból kiderül, hogy keresztény földesuruknak a 17 . század második felében lábbelivel is adóztak a községek. PI. Sántoson szandált adtak évente bőr szárakkal, Hajmáson egy pár csizmát, Nádasdon börszárakkal botost, Galloson (Gálosfa) karmazsin botost ${ }^{13}$, Nagybajomból szandált szolgáltattak be ${ }^{14} \mathrm{~A}$ keleti ízlést képviselő csizma meghonosodása a 16 . század végén történt a Kárpát-medencében. A növényi cserzéssel készült kordován csizma bőrét feketére festették, de karmazsin volt a neve, ha vörösre színezték. ${ }^{15} \mathrm{~A} 18$. század elején is divat volt még a lábbelivel való fizetés. 1702ben Szentkirály bérletéért a kadarkútiak 1 pár karma-

9 Kis patások finomabb bőrét használták fel, mint a juh, kecske, birka. A kívülröl-belülröl ázott, esetleg tömlöre húzva cserzett bör neve kordován, marokkói vagy szattyán, vagy török bőr volt.. Flórián M. 1999..7.

10 SML Protocollum. Generalium et Particolorum IV. 1.a. 518-528. 1737. Marcali.

11 Gáborján A. 1966. 145

12 Valentényi G. 1909. 8.-9. Kertay F. 1936.28. szerint először Pécsre költöztek török kordovánosok és létesítettek cserző mühelyeket.

13 Botos börtalpú, gyapjú szövetből való hosszú szárú lábbeli ez esetben. Gáborján A. 1977. 357.

14 OL UC E 156 44-46. Simontornyai uradalom 1680.

15 Gáborján A. 1977. 520. Flórián M. 1999. 7. zsin csizmát szolgáltattak a tulajdonosnak. ${ }^{16}$ Faisznál megjegyezték az összeírók, hogy nincs a cserzéshez szükséges szemercefa. ${ }^{17} \mathrm{~A}$ feudális fizetési módoknak is fontos része volt a ruha és a lábbeli adása uradalmi alkalmazottaknak a libériás belső szolgáktól kezdve a gazdaságban alkalmazott kocsisig, egyszerü béresig vagy pásztorig. Magasabb beosztású uradalmi cseléd csizmát, alacsonyabb besorolásúak bocskort esetleg bocskor fejelést is, vagy sarut kaptak szárral a 18. században, esetenként bakancsot. A saru a 19. század közepére elmaradt a bértételekből, de a bocskor még azután is része volt a pásztorok, csőszök természetbeli fizetésének. ${ }^{18}$

A tímárok eredetileg a bőr kikészítésén kívül elsősorban bocskort varrtak és sarut, de a 18. században már egyre inkább a vargák kiváltsága maradt e termékek gyártása és a tímároknak csak a bőrkikészítést, talpak előállítását engedélyezték, a bocskor és saru varrását, árusítását korlátozták számukra. A vargák is készítettek lábbeli alapanyagokat, bocskort is, és hoszszúszárú sarut gyermeknek, felnőtteknek, a 16. század végén már cipellőt is.. ${ }^{19}$ de a 18 . században már nyugati típusú sarukat is.. A saruhoz kapca is járulhatott, mely rövid szárú harisnyaféle. Bocskorhoz, papucshoz, később csizmához is viselték, Előállították gyapjúszövetből, nemezből is bőrtalpalással. Ritkán bőrből készült, mint a janicsár kapca is melynek belső felén volt a füzése. A kötött kapcák, harisnyák a 17. század végén jelentek meg a megfelelő kapcakötő mesterekkel. Önálló lábbeliként Somogyban a rövid szárúra kötött és szilárdabb anyaggal pl. bőrrel megtalpalt tutyi futott be karriert nemcsak minden somogyi német csoportnál, de föképp a külső-somogyi és Kapos menti magyaroknál is. Nőknek hímezték a lábfej feletti felületet, házilag is készült, de tartósabb darabokat tutyis mesterektől vásároltak. A bocskorhoz lábbőr, habda, harisnya, szár is járult puha bőrből különböző hosszúsággal, melyet bocskorszíjjal erősítettek a lábhoz. ${ }^{20}$ A botosnak csak a talpa, kérge, káplija készült bőrből, szára posztóból vagy szövetböl. ${ }^{21}$ Somogyban a bocskor és saru árusítása miatt a 18. században a vargák bevádolták a vármegyénél a tímárokat. 1818-ban és 1830-as években pedig a csizmadiák panaszolták be őket, hogy visszaélnek kiváltságos helyzetükkel és túl drágán adják a bőr készítményeiket. ${ }^{22}$

16 OL UC E 156.. 32:14 Szigeti kamarai kerület

17 OL UC E 156. 96:6//1-4. Szigetvári provisoriátus. A szömörcét Dél-Európából telepítették be. A Dunántúlon a Mecsek hegység környéke, a Balaton felvidék illetve Veszprém megye meszes talaja kedvezett a termelésének.

A karmazsint vörös színre festő buzér gyökeréböl és török pirosító magjának fözetével érték el. Sárgára kökény és sárga bogyó fözetével festettek. A szattyán volt a maga színében is. Nagy L. 1971.182- 240, 1984. 591- 530

18 Knézy J. 1986-7. 296-310.. 1997. 145-168.. A csikósok, juhászok elöbb kaptak csizmát, mint a kanászok.

19 Flórián M. 1996159.

20 Gáborján A. 1980. 35 Kapca, börkapca, de lehetett szörös bör, vert nemez, szövött gyapjú vagy vászon is

21 Flórián M. 1997. 685.

22 Szili F. 1988. 87 Csak a vásáron árulták a bőrt a megye által limitált áron, háznál sokkal drágábban. 
A csizmadiák csizmákat, papucsokat és deli sarukat állítottak elö, melyek török hatásra terjedtek el. A régi magyar módra való csizma sarok nélkül varródott illetve fasarok nélkül. A 18. században már a német vargák hatására funtos talppal, sarkosan is varrták, fejét toldva és halzsírral kezelt bőrből szabták, szárát merevre bélelték. Francia hatásra jelent meg a piros sarok, és általában az alapszíntől eltérő színű díszítés, de a sarkantyú is, melyet a sarokra szegeztek. Puha talpúak voltak, de merevebbek az oldalukba fogott kampók, sarok és orrvasalások miatt.

A saru elnevezésü lábbelik az évszázadok alatt többféle változáson mentek keresztül, egyes elemei nyugati, mások keleti eredetüek. Volt pántos saru, amely bizánci eredetű, két füle, két kötője és szorító szíjai is voltak. Nagyobb változatosságot mutatnak a hosszú szárúak, ezek korábbi neve valószínű szekernye volt. Nagyon hosszú szárú készült a vadászoknak, úton járóknak, sokat fuvarozó kocsisoknak. de halászoknak is. Akadt térdig érő ezt nevezték deli sarunak, akadt még rövidebb is. A 15. században már hosszú szárúról beszélhetünk 16-17. században a legáltalánosabb és legjellemzőbb lábravaló. A vargák saruinál a fölső rész bőréhez kívülről varrták a talpat, akár 2-3 darabot is, de hosszú, puha szárát térdzsineggel kellett a lábhoz rögzíteni. A varrás körben látható volt. Kemény talpa miatt télen is viselhették, egyforma volt a nőké, férfiaké, sőt egylábas is. Szögletes orrú is előfordult. A finomabb saru kordovánból és karmazsinból, a hitványabb szattyánból varródott. Szára teteje nyugati módon elől kerek, vagy keléti módon középen emelkedőre lett szabva, és szára nyugati módon hátul varrott, vagy keleti módon kétoldalt. A szára felül kihajtott is lehetett. Bokáján simára ványolták, sima lett a feje is, de volt ráncos torkú is, vagy toldották, mint a kéményseprő papucsát. A férfiak sarujára esetleg sarkantyú is került. ${ }^{23}$

A csizma talpát a kifordított fejhez varrták hozzá, csak a sarokvarrást fejezték be kívül. Mikor visszafordították, a varrás nem látszott, de a fejrész kissé felfelé hajlott. ${ }^{24}$ Magyar csizma alapanyagának kedvelték a bagariát, ez halzsírral pácolt, nyír-, cser-, vörösfenyő-, nyárfakéreg levével kezelődött, meszezés után rozs, zab és kutyaürülék ázalékával tartósították. Szárát kétoldalt varrták, ritkán díszítették belevarrott színes csíkkal. (1. kép) Sokáig egylábas volt, azaz mindkettő egyforma, így bármelyik lábon lehetett viselni. E régi csizmának a lábfeje és szára egy darabból készült, nehéz volt több talpat is varrni rá. Idővel a szára keményebbé vált, magától is megállt, felül lekerekítették, vagy szívalakra vágták. A csizma talpa aránylag vastag volt, a tüskékkel bevert orr-, talp- és sarokvasalást és a patkókat elbírta. Sarka lett nyugati hatásra, s így télen is hordhatóvá vált. $A$ vasalt csizmák hatására a nyugati cipőkre is tettek bőrlapokból való vagy bőrrel borított fasarkot. ${ }^{25} \mathrm{Az}$ egy darabból varrt csizma-

23 Gáborján A. 1991. 293

24 Flórián M. 1999. 8. pontos leírása alapján.

25 17. században csizma: „magyar módra azaz stekli azaz sarok..., fa stekli nélkül" Gáborján A.1966.116.

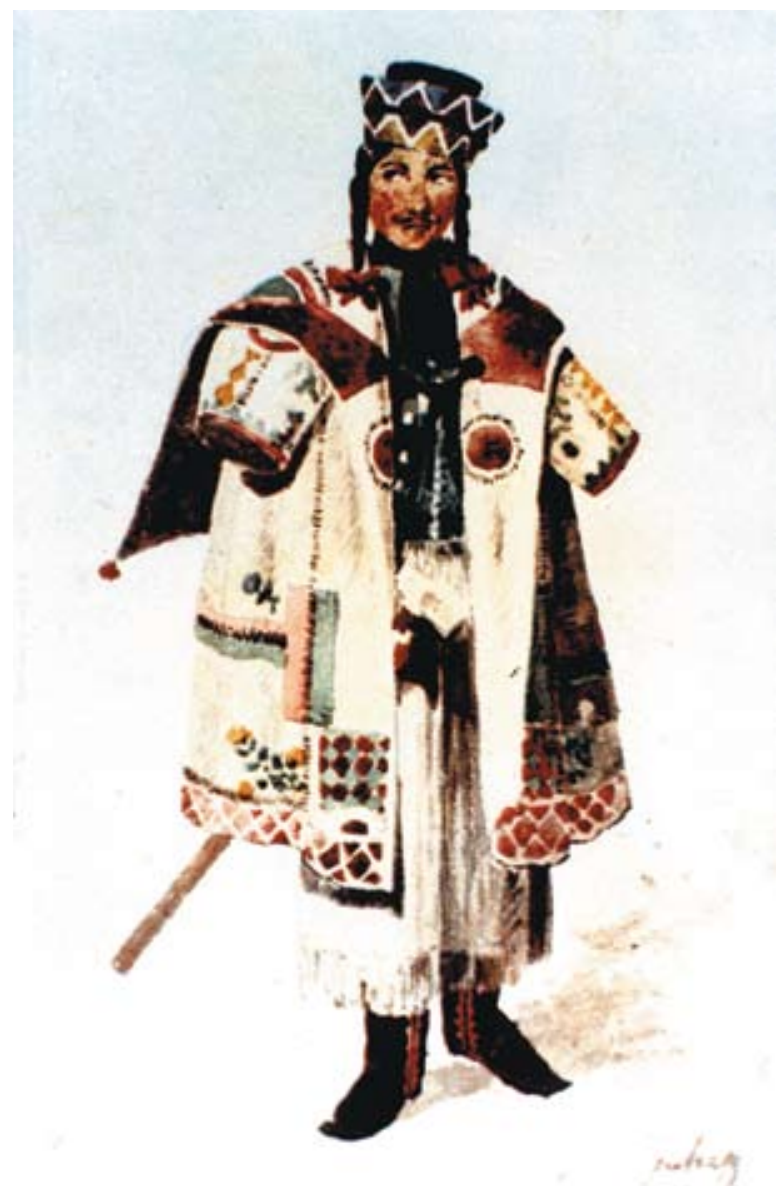

1. kép: Somogyi juhász díszes börcsíkkal díszített oldalvarrott egylábas csizmában, Sobri kalapban,

sodort hajjal, befenekelt ujjú szürben 1830-ban

Szemlér Mihály vízfestményén. Szépmüvészeti Múzeum. Repro negatív.

Magyar Mezőgazdasági Múzeum 213899.

fej és lábszár esetén az elől lévő hajtását meg kellett nyújtani, ványolni és ettől ráncos vagy kimódoltabban harmonikás lett. A zsinórozás már a 18. században megjelent. (szőr-, selyem-, sőt aranyzsinórozás is). A 19. században a csizma fejét és szárát egyre inkább két darabból varrták, így könnyebb volt újra talpalni. A lábfejre a szár egy nyelvszerü nyúlvánnyal varródott. Egyre inkább szegezték az egymásra rögzítendő részeket. Ha a sarok és a lábszár közé egy összehajtott bőrdarabkát varrtak, ez volt a ráma, de tettek rá láncot, csörgőt is. A 19. század végétöl elterjedt a keményszárú csizma is. (2. kép)

Az évszázadok során e mesterségek hatottak egymásra. A suszterek, németvargák vagy cipészek a 18. század elején jelentek meg. A cipészektől, azaz a német vargáktól megkülönböztették a magyar, tót-, horvát- vagy bocskoros vargát, bocskorost. A német tiszteknek a német vargák hosszú szárral készítették csizmafélét, neve stibli vagy stivli volr, Nehéz megkülönböztetni a valódi csizmától a Stiefeltől, ráadásul s somogyi mesterremek leírásokban stifedli is szerepel, 


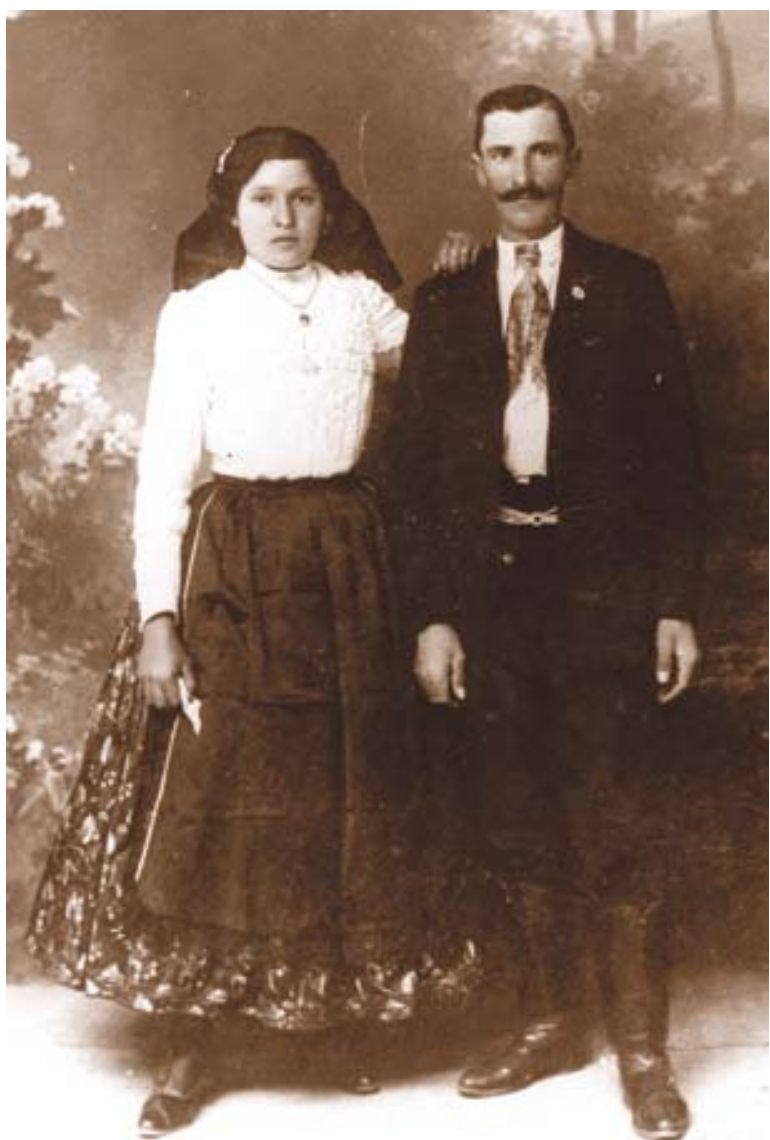

2. kép: Módos református fiatal házaspár, Tóth Andor és felesége 1918. A férfin keményszárú csizma, feleségén oldalt gombos brunellcipö.

Kaposvári Múzeum Néprajzi Fotótára RRM NF 4020.

mint a német vargák készítménye. A német vargák magyar csizmát is varrtak német fejre az 1812. évi Somogy vármegyei árszabás szerint, tehát a fejét és szárát két darabból illesztették össze. A cipészek német vagy osztrák börökböl dolgoztak, cipellőst, topánkát, bakancsot, félcipöt, spanglis cipöt, (3. kép) gamáslit, papucsot illetve pantoflit is készítettek, de rövid és hosszú szárú sarut is gyártottak. Gyakori volt a nem bőrből való felsőrész is, különösen a női cipőknél, topánkánál bársonyból, ebelaszatinból vagy vászonból, és fa- vagy bőr sarokkal, volt 2-3 pántos, és lehetett rézkarika is a sarkán. ${ }^{26} \mathrm{~A}$ felső részt ki is vágták. Nem alkalmazták a talp és fej összeillesztésének kifordított varrással való megoldását, sarut is, cipőt is két vagy több talpra tudtak előállítani. Cipőkkel magyar vargák is foglalkoztak. A német cipészeken kívül mindegyik mesterségre jellemző volt eredetileg, hogy bőrkikészítéssel is foglalkozott. A 19. században a csizmadiák egy része már kész bőrből dolgozott.. ${ }^{27}$

26 Gáborján A. 1977. 122

27 Domonkos O. 1991.71-94. Flórián M. 1997. 683-693.

\section{Bőrrel és bőrlábbelivel dolgozó mesterek helyzete a csurgói magyar céhben (1810-1872).}

A 17. század végi, ${ }^{28}$ 18. századi ${ }^{29}$ néhány önálló bőriparos céhen kívül Somogyban jóval nagyobb számban alakultak már az utóbbi század harmadik felétől vegyes céhek, amelyekben bőrrel foglalkozó iparosok is tevékenykedtek. Csurgón nem volt önálló céh addig és a vegyes céh is viszonylag későn kapott engedélyt a szerveződésre. Még a közeli Nagyatádon is jóval előbb alakult vegyes céh 1775-ben. ${ }^{30}$ Vásártartási jogot is előbb kapott, mint Csurgó. A Festeticsek csurgói uradalma jelentős számú iparost, így bőrrel dolgozókat is szíjgyártót, csizmadiát, németvargát, tímárt - telepített le elsősorban az 1770-es évektől kezdve. Az elhullott, levágott uradalmi állatok bőrét a helyi bőrkikészítő és feldolgozó iparosokkal vetette meg, árát esetenként késztermékkel fizették ki árszabás és szerződések alapján. Az iparosok ekkor az uradalom védelme alatt álltak, jobbágyként vagy zsellérként házat, telket kapva telepedtek le, amiért árendát fizettek, a robotot is pénzzel váltották meg. Esetenként termékeikkel is fizettek, vagy pénzért vásárolta meg áruikat az uradalom. A csurgói vegyes céhhez szép számú Landmeister kapcsolódott, ${ }^{31}$ akikröl külön jegyzéket és bevételi könyvet vezettek. A vegyes céh alakulása, de a kereskedők tevékenysége, gyárak alakulása (bőr, festék, pácok gyártásával) a 19. században lendületet adott a kisiparok fejlődésének és elősegítette a mezővárosi fejlődést, a gazdag tárgyi, népmüvészeti kultúra átalakulását, városi divatok terjedését.

$A z$ 1814-ben önállósodott magyar céh iratai nem folyamatosan, töredékesen maradtak fenn 1814-töl kb. 1872-ig. Ezek a következők:

A „csurgói belső vagy magyar céh protocolluma” 266 lapos. 1810-től kezdték írni a céhbe belépettek névsorát 1865-ig. Témái: 1. sz. Céhbeli remekes mestereinek jegyzéke" 1810-50-ig. 6-35. p. 2. sz. „Filiális mesterek lajstroma” 1828-tól kezdve 36-59. p. 3. sz. Filiális mesterek taxafizetése" 1828-59. 6071. 4. sz. Tanulók és mesterek egyezségei 72-131. p. 5. sz. „Rendeletek az inasokkal kapcsolatban 1854. 131-151. 6. sz. Különféle tárgyakról, végzésekről és határozatokról 1846-tól kb. 1870-ig 173-361. p. 7. sz. „1875-1876. évi tárgyalási könyv 362-65. p.”

Külön kötetben vannak a következők:

„Az úgynevezett magyar céhbe tartozó szegődtető és szabadulóknak beigtató lajstromok" 1865. jul. 11. és a Csurgói Egyesült Ipartársulat” 1874-85. 73.p." anyaga.

Az iratanyag legfontosabb értékének tartom, hogy adatokat tartalmaz a mesterremekek készítéséről, az inasok szerződéseiről közte az inasok ruházatáról, de

281696 Kaposvár, 1699. Szigetvár, 1701 Nagybajom, 1716. Kaposvár, önálló csizmadia céhe, önálló varga céh, 1697 Szigetvár, 1748 Kaposvár. Domonkos O. 1991. 17. és 16. térkép 74-75.p.

291867 Nagyatád i csizmadia céh

30 Gőzsy G. 2001. 145-147. A Czindery uradalom adatain kívül SML Czindery fasc. No. 1018. Idézi Bánhidi Burics L. 1938. 52-55. könyvének adatait is.

31 Knézy J. 1997. 145-187. 


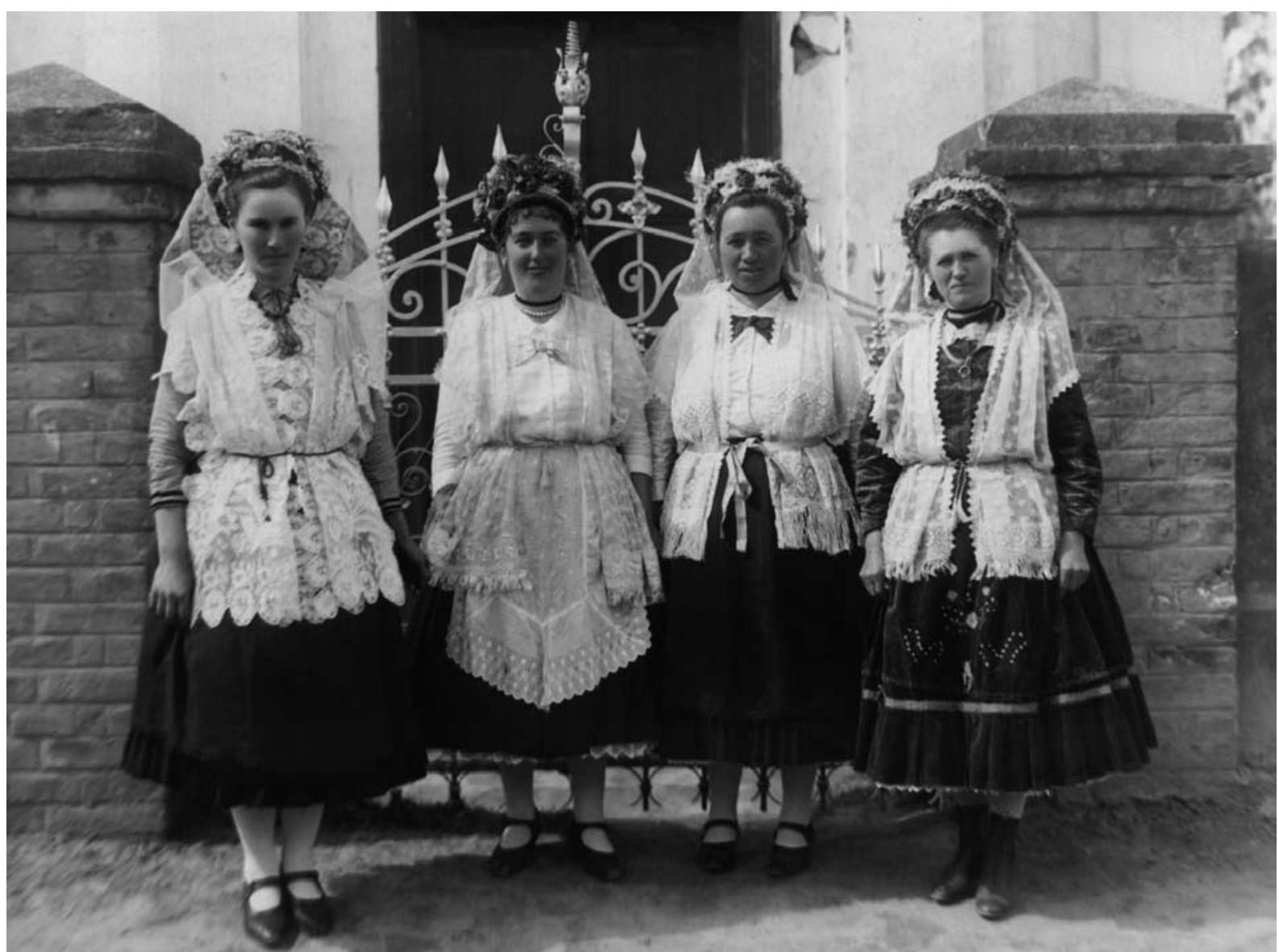

3. kép: Zselickisfaludi menyecskék ünnepi viseletben, egyiken hosszúszárú, a másik három asszonyon magas sarkú pántos félcipö. Gönyey Ébner Sándor felvétele 1930.

még a lábbelikről is. E témákról más somogyi céhektől is rendelkezésre állnak különböző időkből, különböző részletességű feljegyzések. A mesterremekek nem mindig a legújabb divatot tükrözték, hanem a mesterségbeli tudás zsinórmértékét, az igényes elkészítés mód és a díszítés mikéntjét. Sokszor készíttettek hagyományos darabot a mesterjelöltekkel, amellyel leginkább bizonyíthatták rátermettségüket és alkalmasságukat a szakmára. 1716-ban az igali csizmadiáknak mesterremekként egy pár papucsot kapcástól kellett elkészíteni mester- illetve tanulólevelelük bemutatása mellett, és egy aranyat betenni a céhládába, továbbá köszöntő poharat adni, ha jóváhagyták munkáját, az értéke szerint, továbbá mesterebéddel szolgálni és magyar forintot betenni a céhládába. ${ }^{32}$ 1749-ben a kaposvári tobak vagy varga céhben a mesterremek a következő volt két pár halásznak való saru, az egyike két darabból térdig szárral, a másik négy darabból való valamivel kisebb szárral és két pár cipellőst németesen két talpra céhmesterek előtt és őket étellel, itallal ellátni. ${ }^{33} \mathrm{~A}$ saru formája sokat változott a németvargák

32 SML IX. Testületek, céhek 11. sz. Igali csizmadia céh levele magyar nyelvü másolat

33 Kanyar J. 1967. 99. SML IX. 15.z. Vegyes céhiratok Kaposvári vargák 1748 (dombóvári, ozorai céh iratai 1748-49.) másolat illetve suszterek megjelenésével, de a 19. században Csurgón ritkábban szerepel, mint mesterremek, annál inkább a csizma, bakancs, cipellő, topánka. papucs.

A cipellő, cipő Gáborján Alice szerint lehetett száras, bakancsféle, füles, szorító szíjas, belső oldalán füzős lábbeli, gombos, oldalt gombos. (2. kép). Előnye, hogy több talpa is lehetett. ${ }^{34}$ A 19. században a felső része olykor bársony, masnis is, gyakori volt a hímzett tüzött is. A bakancs is magasszárú, füzős, a köznép számára is gyártott lábbeli. A topánka, cipellis félcipőféle. A pántos, spanglis változata fiatal nőknek készült és többnyire ünnepre, esetleg tánccipőnek is. A finomabb női cipőfélék városias helyeken a nyugati országrészben és a Balaton mellékén a reformkorban már a módosabb parasztasszonyokon és lányokon készült rajzokon, vízfestményeken is láthatók. Somogyban mezitlábas és magasszárú cipős nők láthatók az ábrázolásokon ebből az időből. A magas szárú cipő köznapra parasztasszonyoknak fekete színüre készült még a 20. század első felében. Barna színű cipőt „sárgát” csak a módosabbak engedhettek meg maguknak. A félcipő, spanglis is többnyire fekete bőrből való volt. (3. kép)

34 Gáborján A. 1977. 434 
A 19. századi bőr lábbelik, mint a mesterremekek mutatják azt a sokszínüséget, amely a lábviselet területén uralkodott, bár csak sejthetjük, hogy melyik társadalmi rétegre volt egyik-másik készítmény általánosan jellemző. Megkönnyítették a segédeknek, hogy mesterremeket készíthessenek a költségek mérsékelésével. 1805 után a mesterebéd vagy asztal adásának kötelezettségét számos céhirat kifejezetten megtiltotta a pályázók szegénységére hivatkozva. Királyi parancsolat tett javaslatot 1805-ben többek között a mesterremek készítés körülményeire, a kispénzű legények támogatására a remekkészítés költségeiben, de az inas tartás körülményeire is. ${ }^{35}$

A 19. század közepéröl való adatok jól tükrözik azt is, hogy átvételek történtek az egyes bőrös szakmák között. Az is szembetűnő hogy ugyanabba a szakmában tartozók pl. nem ugyanazt a fajta darabor készíttették mesterremeknek. Mivel más részletes leírás az adott időben hagyományos lábbelikről alig akadt, pótolja az adatok hiányosságait a mesterremek igények jelzése. ${ }^{36}$ Többé-kevésbé minden bőrlábbeli készítő mester munkájáról szó esett az iratokban, de nem egyforma részletességgel. $E$ korszakban nem voltak nagyon szigorúak a mesterremek elfogadásánál, mint korábban, amikor ritkábban esett szó a hibák pénzen történő megváltásáról, vagy csak kevesebb hibát fogadtak el. A cél az volt, hogy az igényeknek megfelelő mennyiségü iparos lássa el a lakosságot. A törvény előírta, hogy kontár ne legyen, de aki dolgozik és elad, valamiképpen kötődjön a céhhez, hogy ellenőrizni tudják, és adózzon. ${ }^{37}$

A bocskorkészítők mesterremekeiröl kevés adat van, és nem elég részletes, pedig többen is tevékenykedtek e területen és a helyi, a közeli kanizsai, de a Dráván túli vásárokon is jobban tudták eladni áruikat, mint a többi bőrrel dolgozó iparos is. ${ }^{38}$ Különösen sok bocskor kelt el azon Dráván túli vidékeken, ahol egyes területeken egész éven át bocskorban járt a köznép, míg Somogyban a Dráva menti horvátokat kivéve, csak a legszegényebbek viselték éven át. A módosabb parasztok az 1910-es évek után elhagyták viselését (4. kép), csak a nyári dologidőben főképp aratáskor használták. Meg is szólták azt a jómódú parasztlányt Csökölyben az 1940-es évek elején, aki állandóan bocskorban járt. Sajnos Somogy megyéből nincs részletes leírás erről a mesterségről. A 20. században ismerték a kanca- vagy szijas bocskort a somogyiak, melynél egy darabból szabták a talpát és felső részét,

35 A 18. század második felében királyi és földesúri rendeletek is foglalkoztak e témával, de általános érvényűvé a 19. százada elejétöl vált. A céhek iránt kiadott királyi parancsolat 1805. március 18.i.nyomtatvány

36 Flórián Mária mintaszerűen elemezte a Vas megyei köznép ruházatának illetve lábbelijeinek leírásánál a 18. 19. századi árszabások adatait is. Flórián M. 1996. 180.

37 Külön összeírás készült a kontárokról és külön a céhes mesterekröl. pl. 1831-ben Hárságyról van összeírás csak a kontárokról SML Különféle összeírások 1792-1850. k. 1852-ből több céhröl maradt fenn teljes összeírás a tagokról - ezek a céhes iratokban találhatók.

38 Bánhidi Burics L. 1938. 55. Mindez az első világháború után megszűnt az országhatár megváltozásával.

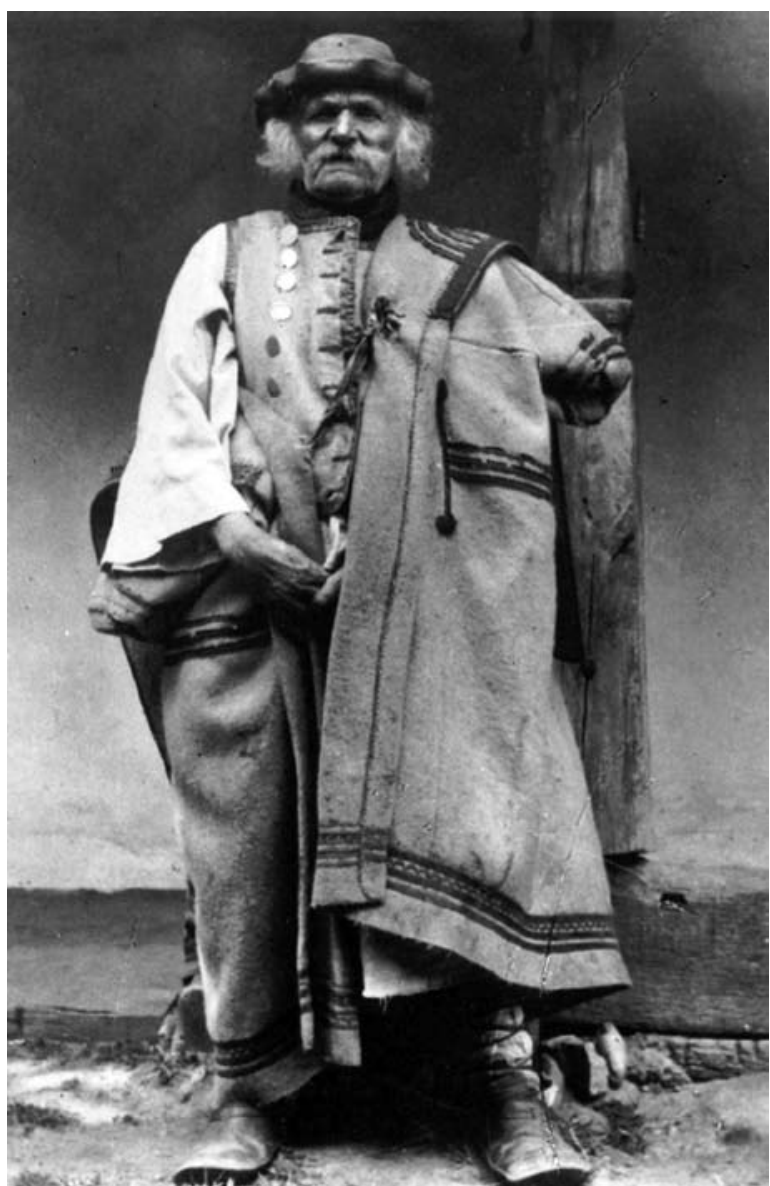

4. kép: Csökölyi református parasztember 1910-ben Garay Ákos felvételén bocskorban fémgombos fehér szürposztó mellényben, gatyában és befenekelt ujjú ún pógárszürben. Ethnológiai Fotótár EF 11528.

nem volt sarka. A bőr szélébe vágott lukakat nevezték teleknek, az összefüzött bocskor neve telekes bocskor volt a 18. századi, 19. század eleji árszabásokban is, de a népnyelvben is. Lehetett kerek vagy hegyes orrú is. Somogyban, ha a lábfej felett összevarrták a bőrt nevezték fejes bocskornak, orra így hegyes lett. A bőrpánt felment a térdig, vagy lábszárközépig. Akadt egylábas, ahol egyforma volt mindkettő és féllábas azaz balos és jobbos. A 20 század első felében már csak a pásztoroknak és idősebbeknek készült a telekes bocskor Dél-Somogyban. Általában a pásztorok maguk is elkészítették, de ők nem használtak sámfát, mint a képzett mesterek. Előfordult főként pásztorok hagyatékában bocskortalp és bocskorszíj is, de a bocskorok paraszti megrendelői is rendelkezhettek ilyen alapanyaggal. A puhaszárú csizma fejének tönkremenése után a szárából a pásztorok elkészítették a bocskort, ehhez szíjinak való marhabőrt tímároktól vettek vásáron. A somogyjádi Körü János kanász a 20. század elején a lukakat a bőrdarabra bicska hegyével fúrta és szarvasagancs csúcsával tágította kit, a bocskort lábikráig felkötve viselte és lábfején vászon kapca- 


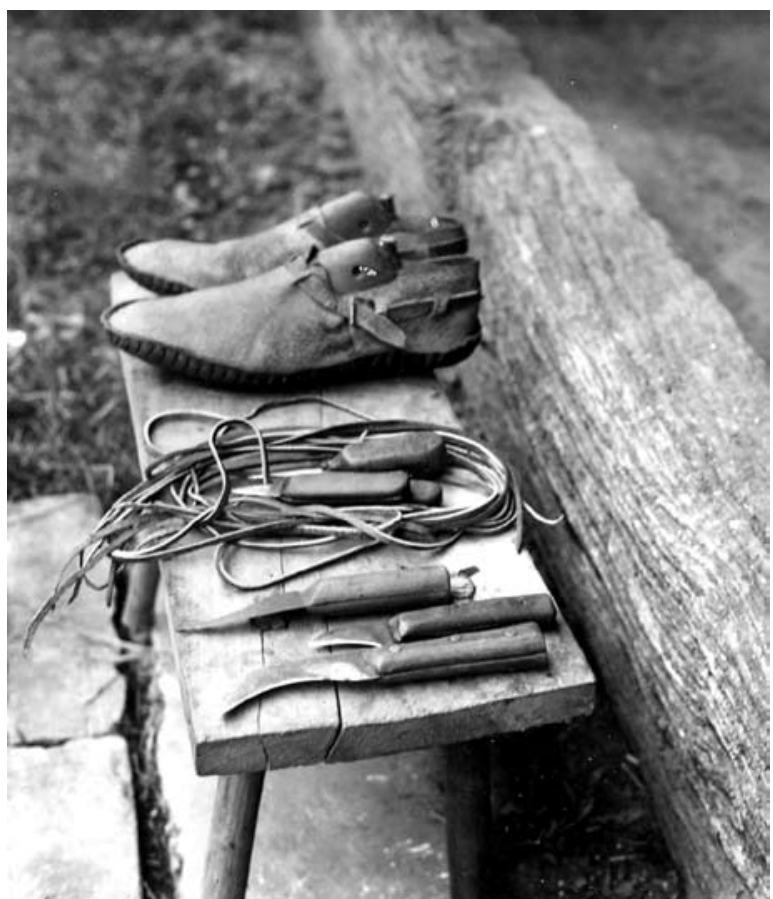

5. kép: Jelics Pál lakócsai bocskorkészítő utolsó bocskora és szerszámainak töredéke. Knézy Judit felvétele 1975.

ruha volt. Másoknak 20 krajcárért füzött bocskort. ${ }^{39}$ A zselici uradalmi cselédek és pásztorok a 20. század elején már tompaorrú födeles bocskort viseltek, amelyet a bokájuk köré tekert négy szíjjal füztek a lábukra. Föképp akkor hordták a pásztorok a bocskort, amikor a tarlón legeltették az állatokat. Puhaszárú csizmából ők is füztek bocskort, keményszárú csizmához nem jutottak, azt nem tudták megfizetni, csak módosabb parasztok $^{40}$. A rangosabb fedeles bocskort talp és felső részböl varrták össze. A Dél-Alföldön és Dunántúlon általánosan elterjedt. Díszítették is szironnyal, színes bőrpánttal. Legkésőbb már a fedeles csatos bocskor került divatba, ez körbefogta a lábat - mondta el Jelics Pál az utolsó somogyi, lakócsai horvát bocskorkészítő. (5. 6. képek) Az itteni horvátoknál az első bocskort az iskolát kezdő gyermeknek készítették. A halottakat csatos bocskorban illett eltemetni. Jelics Pál elképzelte, hogy, ha feltámadnak a lakócsai halottak, akkor mindannyian csatos bocskorban jönnének elö. A varrószíjat ő ló bőréből készítette, melyet maga cserzett: gubacsot ledarált és három hónapig áztatta benne a bőrt, amelyről a gubacslé levette a húst is és a szőrt is, megszárítva téglácson puhította és felszabdalta 4-es, 5-ös, 6-os méretüre... Ez a mester azzal dicsekedett, hogy neki 800 pár kaptafája volt. ${ }^{41}$ Járulhatott a bocs-

39 Takáts Gy. 1986. 10.

40 Eperjessy E. 2006. 228.

41 Saját gyűjtés 1975-ben Lakócsán. A két világháború között még Barcson, Drávasztárán, Sellyén dolgozott egy-egy bocskoros, Szigetváron kettő is. Jelics Pál Szigetváron tanult, ahol két segéd és két inas is dolgozott. Az ő talpas, zsuppos háza fennmaradt és berendezésre került tájházként. Kapitány Orsolya munkájaként. korhoz szár is bőrböl, vagy télen különösen kapca is szőrős bőrből, gyapjúból vagy vászonból.

A bocskorosok vásározási életviteléről jóval többet megtudunk, mint a mesterremekelésük körülményeiröl. A különféle kihágások, veszekedések kiderülnek a büntetéspénzek jegyzékeiből. A késő tavaszi, nyári, őszi búcsúk és vásárok helyszínén a helyfoglalások miatt voltak viták, de a vásár utáni kocsmázások borgőzős állapotában bármi miatt összeszólalkoztak a bocskorosok és a vargák. Dobrovits József (Dobrovetz-ként is szerepel) 1845-ben a zákányi búcsúban Pavlicsek vargával, a legényével és másokkal összeverekedett, ingét leszaggatták, a helybéli oskolamester meg is huncfutolta. Mindegyiknek büntetést kellett fizetnie. ${ }^{42}$ 1846. június 11.-én jegyezték be, hogy Dobrovetz József „a szentmihályi hegyben múlt pünkösdi búcsúkor ... mise elött botskorait árulta, miről megintvén őtet az ottani varga mesterek, nekik engedelmeskedni nem akart. Ez okból Pavlitsek György zákányi varga Dobrovetz egy pár botskorát elvivén eladta, az árát pedig a vargák közönségesen felborozták. Dobrovetz nem akarván munkáját elengedni, ötet a többi vargák megverték az ingét öszve szaggatván." A bocskoros nem árulhatott, de megveretése miatt a büntetéstöl a céhbírák eltekintettek. Az önbíráskodó Pavlitseknek meg kellett térítenie a bocskor árát. ${ }^{43}$ 1847-ben szeptember 26.-án az (iharos) berényi vásárban egy Markovits József nevű bocskorossal történt baj. Gyalog ment Csurgóról, útközben két bocskoros társa - a fent említett Dobrovetz és Poszek nevűek - kocsin menve elhagyták őt, és a helyszínen elfoglalták a szokott helyét. De mikor megérkezett, átengedték neki, mégis szóváltásra került sor és öszve huncfutolták egymást. ${ }^{44}$ Markovits Józsefet illetlen ruhaviselésért ítélték $2 \mathrm{ft}$ pénzbüntetésre, mert mind a gólai, mind a bükkösdi búcsúban pöre gatyában árult és nem az iparosokhoz méltó öltözetben. ${ }^{45}$ Egyetlen adatot idézek bocskoros mesterremekről:

- 1857-ben Bausza (vagy Gansza) György belovári bocskorosnak két pár fejes bocskort kellett remekül készítenie Dobrovits Józsefnél, terv szerint: egyik pár az első fára, másik pár a második fára fogja varrni. Tíz hibája ellenére elfogadták mesternek. Szerepelt a remekes mesterek között már 1856-ban. ${ }^{46}$

A paraszti viselet gazdagodása, közelítése a városi divathoz a lábbelik készítésének változatosságán is lemérhető. $A$ bocskor részben háttérbe szorult illetve a mezei munkák idejére. A hűvösebb időkben és föként ünnepen a csizmák, bakancsok, cipők voltak jellemzőek. A szegényebbek inkább a cipót „cipellőt, bakancsot „topánkát” tudták megfizetni. Az egyszerübb, hétköznapi lábbelik készítése ritkábban szerepelt a mesterremekek között, hanem inkább a díszesebb, rangosabb ünnepi darabok mind németvargák-

42 SML IX. 3. Különféle tárgyakról, végzésekröl és határozatokról 1845. 189.p.dolgokról

43 Ld SML IX. 3. 179-80. p.

44 SML IX. 3. sz. 189.0. p.

45 SML IX. 3.sz. 200.p.

46 SML IX. 3. Különféle tárgyakról .280. Tanulók és mesterek egyezségei. 110. $p$ 


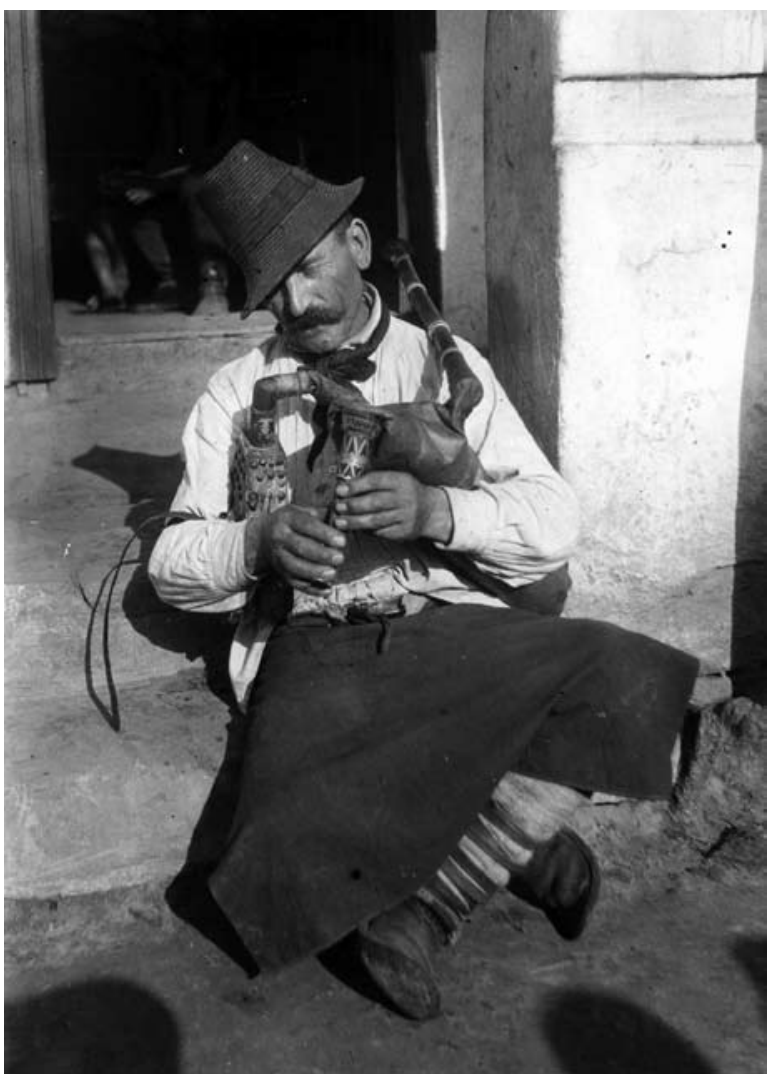

6. kép: Horvát dudás Potony 1926. Gönyey Ébner Sándor felvétele

nál, mind a csizmadiáknál. Feltűnő a reformkorban és az 1850-60-as években Csurgón és környékén is a csizmadiamesterek magas száma. A 151 belső céhbeli remekes mesterek között 1828-72 között 38 fő csizmadiamester került bejegyzésre, Nem különböztettek meg német és magyar csizmadiát, hanem a finomabb árut rendszerint a németvarga mesterek készítették, akiknek száma 1828-72 között 12 fő volt.

- Ferenczi Pál Fazekasdentsen lakó németvarga remekül 1847-ben egy pár wix stifelt ${ }^{47}$ és egy pár német csizmát, egy pár kecskebőr cipellöt ${ }^{48}$ készített. 24 évesen lett mester. Csak 1882-ben halt meg 35 évi mester tevékenység után. ${ }^{49}$

- Fekete Sándor csizmadia legénynek 1848-ban feladata lett remekül: 1. kordovány férfi csizma magas steklire (sarok) és tüzött (?hmzett) struklikra 2. sárga kordoványból asszony csizma, a fejbör szívre kivágva, szegylet talpra és bélések mindenütt egész bőrből legye-

47 Frecskay J. 1912.53." a vixstiefel, stifli, (wiichs leder): feketített borju bőr, fejbőr, korom, faggyú, viasz keverékével kikefélve, növényi cserzésü, magas zsírtartalmú. mázzal bekenve, fényezve.

48 A két elnevezés mutatja, hogy különbözött a német csizma és a stifeltől. A cipellő valószínű szattyán. Gáborján Alice szerint a cipő, cipellős több- de egytalpú is lehetett, gombos is, fa- és bőr sarkú. 1977. 434.

49 SML IX. 3. Sz. Remekkészítés a különféle tárgyakról, végzésekről, határozatokról 90.p 23. bejegyzés. Remekes mesterek jegyzékében 21. p.75. bejegyzés nek a szára pedig meg légyen zsinórozva ..." Bárány Ferencnél kellett elkészítenie. ${ }^{50}$

- Horváth János csizmadia remeke 1849-ben férfi csizma, asszony csizma, de hogy sárga kordoványt nem kapni, fekete csizma lesz vörös steklire (sarokra) láncolássa. ${ }^{51}$

- Krizsek József németvarga remeke 1849-ben: egy pár vixleder ${ }^{52}$ csizma és egy pár nyelvre kivágott ${ }^{53}$ férfi csizma mind a két pár és egy pár cipő piros rámára kecske bőrből. ${ }^{54}$

- Sultz Antal németvargának 1855-ben remekként 1 pár topánkát kellett készítenie fekete brunerből, egy pár papi csizmát ${ }^{55}$ és 1 pár férfi gamáslit magas sarokra, rámára. ${ }^{56}$

- Dacsek János 1857-ben egy pár nyelves csizmát mutatott be, egy pár vix halb stifli-t, ${ }^{57}$ egy pár cipöt sámfára, melyeket otthon gyártott le. ${ }^{58}$

- Hentzler Ferencnek remekül 1859-ben egy pár bársony stivlit szívre vágva, egy pár nyelves csizmát és egy pár férfi topánkát adtak otthon való előállításra. ${ }^{59}$

- Holi Pál csurgói születésű németvarga mesterremek feladata 1865-ben a következő volt: egy pár bársony stivedli férre tüzve sarokra, egy pár magyar csizma magos sarokra, egy pár czuk topánka, a csizma zergebörből, a topánka vixléderből." Szerepelt még abban az évben a remekes mesterek között. 60

- Szili József 1870-ben egy pár férficsizmát mutatott be ránc nélkülit ${ }^{61}$ zergebőrből fél magas sarokra, szegesen magyar gallérra és szíjat beszegve, asszonycsizmát szegezve, magas sarokra, beszegett szárral. ${ }^{62}$

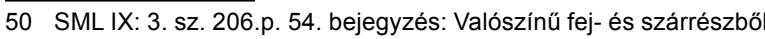
összevarrva, a szárra a fejrész felső széle szív alakban lett rá rögzitve. Igényesen készített darab többek között azért, mert az egész ki lett bélelve.

51 SML IX. 3. sz. 268. p. 104. bejegyzés, a nőknek volt általában piros sarkú csizmája.

52 Fekete borjúbőr magas zsír és viasz tartalmú mázzal fényezve.

53 Nyelvre kivágott csizma: fej és szár részből varrva, a nyelv a fejrészből indul ki és kicsit szűkíti a szárat

54 A piros ráma: a fekete felső rész „felső bőr" behajtott széle és a „talpbör” közé varrt 1-2 cm széles piros vékony bör a sarok külsó kerületén a belső bütyöktöl a külsőig. Ld. SML IX. 3 .sz 216. 75. bejegyzés

55 A topánka női félcipő finom textilanyagból való felső részből. Papi csizma felső papság és förendek elöl szögletesre vágott orrú csizmája, mely a polgársághoz csak a 19. században jutott el. Gáborján A. 1958., 56. Az alsópapságnak a 17. században a pántos saru hordását rendelte el az egyház. Ennek is szegletes volt az eleje. Gáborján A. 1981. 430.

56 A gamásli, kamásli lényegében lábszárvédő, általában nem bőrből való, de ebben az esetben mivel sarka is van, csizmaszerü bőr lábbeli. Ld. SML IX. 3. 276.p. 112 bejegyzés. Kifejezetten német vargák munkája.

57 Stivli vagy stivedli megnevezés hosszúszárú csizmaszerü lábbeli, a halb stifli kurtaszárú változat.

58 SML IX. 3. sz 287.p. Nyelves csizma feje külön volt rávarrva.

59 SML IX.3. sz 299.p. bársony csizma, női lehet, a topánka pedig viaszos fényezésü bőrből való félcipő.

60 SML IX.. 3. sz. Meglehetősen sokat kívántak ettől a jelölttöl

61 Ráncos, vagy harmonikás volt az a csizma, amelynek szára és feje egy bőrből volt és a hajlatnál ványolni kellett. De az újabb fajta csizma ránc nélküli, két részből való nyelves csizma rendszerint hátul varrott, kemény szárú, esetleg lakkozott bőrből készített.

62 SML IX. 3. sz. 359. Magas gallér a szártető kiképzése, vagy símán visszaszegték, vagy magyar móda vágták és úgy szegték vissza. 
- Horvát József csizmadia 10 évi vándorlás után kérte felvételét a csurgói céhbe, remekként egy pár férficsizmát fél magas offszetre, egy pár női csizmát piros steklire, (sarokra) a stekli körül láncolásra kitüzve kellett bemutatnia. ${ }^{63}$

Az inasokkal kapcsolatos rendeletek és adatok is szerepelnek a céh irataiban pl. honnan származnak, hány évre szerződnek, ki a mesterük, kik a pártfogóik, ki fizeti a beállást és a szabaduló pénzt. Megtudjuk, milyen útmutatást kapnak, miként viseljék magukat.

„Mesterségét tanuló inasnak szegődtetésekor eleiben adandó, s olvasandó egynehány regulák, mellyekhez magát szabni, mint egy sinór mértékhez kötelezhetnek:

1. Jó erkölcsű légy, az utcán is mindeneknek szépen köszönj

2. A mühelyt tisztán tartsad

3. Az asszonyodnak szavát meg fogadd, a mesterét mindenek felette

4. Minden szombaton a mühelyt szépen ki tisztogasd, a szerszámot pedig jó helyre rakd

5. Szófogadó légy a visszafelelgetést távoztassad

6. Hírt egyik háztul a másik házhoz ne hordozz, mert ebből legtöbb háborúság származik, sőt idegen dologhoz az inasnak siketnek, némának és vaknak kell lenni.

7. Hogyha valami elveszett dolgot találsz a mühelyben, azt először jelentsd a mesternek, azután a legénynek

8. Ahová küldenek, sietve menj

9. Korán reggel felkelj, legalább 4 órakor".

A szabaduláskor is elmondattak velük regulát:

„Fel szabadulván, ne az inasokkal, hanem a legényekkel társalogjál

A részegségtül, s káromkodástul magad őrízd

A maisztereket szépen megbecsüld

Blau montagot azaz heverő napot magadnak ne tsinálj, mert azért a fél hét le lesz húzva

Annak idejében feküdj le s korán kelj fel, s az éjszakázást távoztasd.

Kundschaft nélkül ne vándorolj, mert anélkül sehol nem vesznek mühelybe."

Általában 3 évre szerződtették az inast a 18. században, de előfordult négy év, sőt több is, mint Igalon a csizmadiáknál. ${ }^{64} \mathrm{Ha}$ a szülö fizette a költségeket elég volt két év is, és nem kellett házimunkákban részt vennie. Ha mester állta a költségeket, hosszabb volt a tanulóidő ${ }^{5}$ és bármi munkát rábízhattak. A 18. századi céhlevelek elég pontosan írták le: mi jár az inasnak, legénynek élelmezés, ruházat szempontjából, míg mesterénél dolgozik és a szabaduló ruházatról illetve fizetségröl is. A kaposvári vargáknál az inasnak mestere fizetett hat pár fehér ruhát, egy borjúbőrt vagy negyven pénzt, egy szürdolmányt és elegendő lábbelit, az inas mig tanul, ezután 5 forintot fizet a céhnek, 2 forintot

63 SML IX. 3. sz. fáémagas offset kurta csizmát jelenthet.

64 SML IX. 11.sz. 1716.

$65 \mathrm{Az}$ 1805. évi Királyi parancsolat ezt szabta meg. társpohárra és 25 pénzt tanulólevélre, 1 forintot a nótáriusnak. ${ }^{66} \mathrm{Az}$ igali csizmadiáknál az inas 25 magyar pénzt fizetett első évben a kasszába, de a többi évben is tartozott valamennyivel. Szegődése utáni időre ez állt: negyed fél esztendő kiteltével félheti bért fizet a mester az inasnak, s ha mind a négy esztendőt kitölti a mestere ad egy öltöző ruhát... morvai posztóból, az inas a tanuló levélért a céh pecsétjéért egy magyar forintot köteles adni. ${ }^{67}$

A 19. század középső harmadában a csurgói magyar céhben a szerződést nem mindig a munkába álláskor rögzítették írásban, hanem próbaidő után vagy később pl. a szabaduláskor, vagy akkor is készült feljegyzés. ${ }^{68} \mathrm{Az}$ inasévek alatti ellátást sokszor nem részletezték, elnagyoltan jelezték, csak hogy mestere élelmezi és ellátja ruhával, lábbelivel szükség szerint vagy elegendővel. Az egyik szerződésben viselt ruha állt. Mindezek a fogalmak lehetővé tették, hogy megkerüljék e szabályokat. Munkaruha címén föleg az ún. vászonruha együttest, a fehér ruhát adták, ez alsó ruházatnak számított már ekkor az iparosoknál, bár melegben felsőnek is megfelelt, vásárra is ment valaki pőre gatyában. Egyetlen esetben jelezték, hogy míg inaskodik a jelölt, fölső ruhával látja el mestere. Nem tudni, hogy a fehér ruha kifejezésben benne foglaltatott-e a kötény is. A 20. században elején Somogyban az iparosok hétköznapi ruházatából elmaradhatatlan volt a kékfestő kötény. Jobban részletezték a csurgói szerződések a szabaduló ruházatot, ami nyilván újonnan készült. A bocskorvargák, németvargák és csizmadiák inasai lábbeliként bocskort sem köznapra, sem szabaduló ruhaként az 1840-es évek közepétől nem kaptak, hanem csizmát, esetleg csak csizmafejelést, vagy a csizma mellett azt is. Egy esetben kapott németvarga inas fél stiblit szabaduló ruházata részeként. Mindenkor rögzítették a szegődés és szabadulás pénzügyi vonzatait, hogy ki fizeti az apa-e vagy a mester, és ki melyiket:

Idézek néhány részletesebb szerződést jelzésképpen az inasok ruhájára vonatkozóan

- Tsirek Miklós 21 éves csizmadia Tapoloveczröl, Körös megyéből szegődött inasnak 1846. dec. 16.-án 4 évre, felszabadulása lesz a múlt Úrnaptól kezdve 4 esztendő. Mestere Bukovits József, pártfogói Kostyák Balázs és Bárány Ferenc. Gazdája ad neki mindennemü viselt ruhát, a szegődőt, felszabadulást a gazdája fizeti. Felszabaduláskor ád néki spencert, nadrágot, posztóból mellényt, nyakravalót, egy pár új csizmát, kalapot, egy vékony fejér ümögöt, addig pedig minden esztendőben egy pár fejér ruhát.

- Császár Jóska 17. éves katolikus bocskorvarga inas, mestere Fülöp Mihály, 3 évre „szegődött 1847 jan 3. szabadult ugyanúgy. Szegődést, szabadulást az inas fizeti, ruhát pedig, míg inas, a gazdája.... felszabaduláskor ad neki spencert, nadrágot posztóból, lájblit, nyakra valót, kalapot, csizmát, fejér ruhát nem.

66 Kanyar J. 1967. 100.p. SML IX. kaposvári varga céh 5. sz. 1748.

67 SML IX. 11. sz. Igali céhiratok

68 A forrás SML IX. 3. sz Csurgói magyar céh Tanulók és mesterek egyezségei 80-131. p. 
Pártfogói Jursetits Imre és Csafuli Jakab.

- Péter István németvarga 13 éves református, mesteréhez Csurgón Ferenczi Pálhoz, 4 évre szegődött 1848-ben, csak 1852-ben szabadult..A szegődést és a szabadulást a mester fizeti, fölszabadulására egy pár fél stiflit ad. Pártfogói Hirt János és Sandtner Tamás.

- Kultsár János 12 éves ref. csizmadia Nemesdéden elszegődött Gál Lajoshoz 1850. december 31.-én. A gazdája ad neki még inas lesz külső viselö ruhát, szabaduláskor egész szabaduló ruhát posztóbul. Szegődést és szabadulást a gazdája tartozik fizetni. ${ }^{69}$

Az összes szerződés ismeretében teljesebb képet lehet adni az itteni inasok viseletének alkalmazkodá- sára a környezetük divatjához legalább ünnepi, ún. szabaduló ruházatukban összehasonlítva a takács-, szabóinasokra vonatkozó adatokkal, de különbségeket is téve pl a németek ruhája esetleg lábbelije is más volt, mint a magyaroké, a nyáron szabadulók szabaduló ruházata nem posztóból készült, hanem olykor vékonyabb anyagból.

Csurgóra vonatkozó legutóbbi munkáimmal igyekeztem a Somogy megyei néprajzi kutatások fehér foltjaiból néhányat eltűntetni és felkelteni a figyelmet a céhekre vonatkozó bőséges források feltárására, és a viselet összefoglalók lábbelikre vonatkozó hiányosságait kissé mérsékelni.

69 SML IX:3. Tanuló inasoknak és tanítómestereiknek egymás között tett egyességek. 78-79.p 8. bejegyzés, 88-89.p.11. b., 84.p. 17. b., 104.p. 53. bejegyzés.

\section{Irodalom}

BÁNHIDI BuRICs L. 1933: Nagyatád nagyközség múltja és jelene. Nagyatád 3-67.

Domonkos O. 1991: Bőr és bőrfeldolgozó ipar. (tímár, varga, csizmadia, szíjgyártó, szűcs, kapcakészítő, kefekötő, fésűs). In: Magyar Néprajz III. Kézművesség. Szerk.: Domonkor O. - Nagybákay P.. Budapest 71-94.

EPERJEssy E. 2006: Puszták népe a Zselicben (1900-1950) Horpács, Mikszáth Kiadó.

FLóRIÁN M. 1996: Hogyan öltözködött a Vas megyei köznép. In: Vas Megye Népművészete. Szerk.: Gráfik I. Szombathely 157-195

FLóRIÁN M. 1997: Lábbeli. In: Füzes E. - Kisbán Eszter. Magyar Néprajz. IV. Életmód. Akadémiai Kiadó Budapest 683-693.

FLóRIÁN M. 1999: Az mesteremberek Míveinek árazása. Tímárok és irhások, bocskorosok, magyar és német vargák, csizmadiák és kapcakötők árszabásai. (1597-1821.) Budapest, MTA Néprajzi Kutatóintézet.

FRECSKAY J. 1912: Csizmadia, cipész, vargamesterség. In Frecskay J. Mesterségek szótára. Ötven iparág leírása. Budapest 53-60.

GÁBORJÁN A. 1958: Két hosszúszárú lábbeli típus viselettörténeti elemzése. Néprajzi Értesítő XL. 543-574

GÁBORJÁN A. 1962: A magyar módra való bőrkészítés problémája. Néprajzi Értesítő XLIV.97-140.

GÁBorJán A. 1977: Botos. Cipő, cipellő. Csizma. In: Magyar Néprajzi Lexikon. I. Szerk.: Ortutay Gy. Budapest 357. 434. 520.

GÁBORJÁN A. 1980: Kapca. Lábbör, habda, harisnya. Magyar Néprajzi Lexikon II. Szerk. Ortutay Gy. 35. p. és 320. p.

GÁBORJÁN A. 1991: Magyar bör- és lábbeli-készítés. Magyar Néprajz. III. Kézművesség. Szerk.: Domonkos O. - Nagybákay P. Budapest 282-308.
Gözsy G. 2001: Újjáéledéstöl a reformkorig. In: Nagyatád története I. Szerk.: Bősze S. Nagyatád 111-157.

KANYAR J. 1967: Harminc nemzedék vallomása Somogyról. Kaposvár Kıss I. 1962: Kaposvár kereskedői az 1700-as években. (Emlékkönyv a Kaposvári Állami Közgazdasági Technikum jubileumáról) Kaposvár 82-93.

KNÉZY J. 1986-7: Uradalmi alkalmazottak és életmódjuk a csurgói uradalomban a 18. század végén. Magyar Mezőgazdasági Múzeum Közleményei 285-310.

KNÉZY J. 1997: Élet a Festeticsek uradalmában a XVIII. század utolsó harmadában. Somogy Megye Múltjából. Levéltári Évkönyv 28. Kaposvár 145-168.

KNÉZY J. 2012: Egy mezőváros céhes iratai. (Csurgó céhiratainak értékei és hiányosságai). In: A céhládától az adatbázisig. Szerk.: Márkusné Vörös H. A Veszprém Megyei Levéltár Közleményei 26. Veszprém 193-203.

KNÉZY J. 2013: Céhes adatok a somogyi pék- és mézesbábos mesterekről az 1810-es évektől 1869.-ig. A Kaposvári Rippl-Rónai Múzeum Közleményei I. 251.260

NAGY L. 1971, 1984: A veszprémi tobakok. I-II Veszprém Megyei Múzeumok Közleményei 189-240, 501- 530.

SZÁDECZKY KARDos L. 1913: Iparfejlődés és a céhek története Magyarországon. Budapest.

SzILI F. 1988: Somogy megye kereskedelme a kései feudalizmus korában. 1700-1848. Kaposvár 3-212

TAKÁTS GY. 1986: Somogyi pásztorvilág. Kaposvár 127.

VALENTÉNYI G. 1909: A Somogy megyei céhek. Szekszárd. 